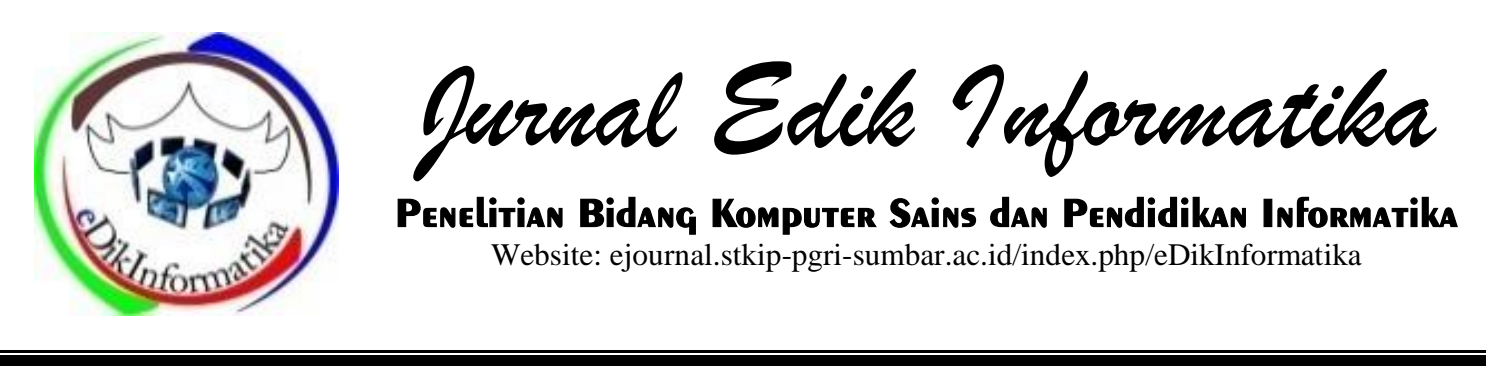

\title{
APLIKASI KALKULATOR KOMPONEN ELEKTRONIKA BERBASIS ANDROID
}

\author{
Ade Setiawan ${ }^{1}$ \\ ${ }^{1}$ Universitas Bina Sarana Informatika \\ ade.dtx@bsi.ac.id
}

INFO ARTIKEL

Diterima:

30 Maret 2021

Direview:

17 April 2021

Disetujui:

28 Mei 2021

Kata Kunci:

Android, Elektronika,

Resistor, Capasitor,

SMD Resistor

\begin{abstract}
Android is the most popular OS today, many of which use android as a learning medium, knowledge and tools for calculating examples such as making electronic component calculators that can help repair technicians of electronic devices. In this study, the authors made an electronic component calculator application that can calculate a component value by reading the component codes carried out by the application. In making this application using Android Studio tools to create the source code. Adobe Photoshop is of course for the design. Of course, this is in line with the purpose of the author's research. The results of research by electronic device repair technicians and students are greatly helped by this application.
\end{abstract}

\section{PENDAHULUAN}

Perkembangan device handphone yang semakin cepat dan pesat baik itu berupa hardwarenya yang dulu menggunakan keypad sekarang menjadi touch screen, lalu dulu kita pernah merasakan mempunyai handphone yang menggunakan operating system-nya yaitu symbian dan java, kini handphone berbasis OS Symbian dan java sudah tidak lagi dipergunakan, hampir semua orang beralih ke OS android. Hal ini disebabkan OS android, memiliki banyak keunggulan dari segala fitur aplikasi yang tersedia dalam $O S$-nya. Tentu hal ini tidak lepas dari peran developer pemrograman android yang membuat berbagai macam aplikasi-aplikasi android. Developer pemrograman android seperti berlomba-lomba membuat aplikasi android yang berbagai macam fungsinya untuk pengguna android sehingga pengguna android dimanjakan dengan adanya berbagai macam aplikasi android tersebut. Contoh pengguna android memanfaatkan berbagai macam aplikasi android yaitu membaca Al qur'an, membaca kitab hadits, membaca kitab maulid, memesan makanan secara online bahkan memesan jasa pelayanan transportasi. Mereka semua pengguna handphone android dipermudah segala aktivitas sehariharinya dengan handphone yang dimiliki. 
Pada pembahasan permasalahan dalam penelitian ini yaitu para teknisi reparasi perangkat elektronika terkendala didalam melakukan reparasi perangkat elektronika yang berhubungan dengan pembacaan komponen elektronika. Ketika melakukan pembacaan kode-kode komponen elektronika, para teknisi kesulitan untuk membaca kode-kode pada komponen elektronika tersebut, yang dimana kode tersebut memang sangat sulit dihafal dan tentu terdapat rumus untuk pembacaan kode komponen tersebut. Kode-kode komponen tersebut menunjukkan nilai satuan suatu komponen elektronika yaitu bisa berupa ohm dan farad yang tentunya nilai satuan komponen tersebut harus sesuai dengan yang tertera diskematik rangkaian elektronika yang valid.

Sesuai dengan penjabaran masalah di atas, maka dalam penelitian ini penulis ingin membuat aplikasi yang berguna untuk pelajar, dan teknisi elektronika yang tujuannya untuk mempermudah segala aktivitas pekerjaan mereka dari pembelajaran hingga troubleshooting pada saat melakukan reparasi perangkat elektronika, untuk memperkuat penelitian ini, penulis mengutip beberapa jurnal yang dimana jurnal tersebut membahas hal yang sama yang dilakukan penulis. Penulis kutip beberapa teori definisi tentang komponen-komponen elektronika.

"Resistor adalah komponen dasar elektronika yang digunakan untuk membatasi jumlah arus yang mengalir dalam satu rangkaian. Sesuai dengan namanya resistor bersifat resistif dan umumnya terbuat dari bahan karbon. Dari hukum Ohms diketahui, resistansi berbanding terbalik dengan jumlah arus yang mengalir melaluinya. Satuan resistansi dari suatu resistor disebut Ohm atau dilambangkan dengan simbolW (Omega). (Setiawan et al., 2019)
"Resistor adalah komponen dasar elektronika yang digunakan untuk membatasi jumlah arus yang mengalir dalam satu rangkaian. Sesuai dengan namanya resistor bersifat resistif dan umumnya terbuat dari bahan karbon. Dari hukum Ohms diketahui, resistansi berbanding terbalik dengan jumlah arus yang mengalir melaluinya. Satuan resistansi dari suatu resistor disebut $\mathrm{Ohm}$ atau dilambangkan dengan simbol $\Omega$ (Omega)." (Kamelia et al., 2017)

"Resistor adalah komponen dasar elektronika yang digunakan untuk membatasi jumlah arus yang mengalir dalam satu rangkaian. Sesuai dengan namanya resistor bersifat resistif dan umumnya terbuat dari bahan karbon. Dari hukum Ohms diketahui, resistansi berbanding terbalik dengan jumlah arus yang mengalir melaluinya. Satuan resistansi dari suatu resistor disebut Ohm atau dilambangkan dengan simbol $\mathrm{W}$ (Omega). Tipe resistor yang umum adalah berbentuk tabung dengan dua kaki tembaga di kiri dan kanan. Pada badannya terdapat lingkaran membentuk gelang kode warna untuk memudahkan pemakai mengenali besar resistansi tanpa mengukur besarnya dengan Ohmmeter. Kode warna tersebut adalah standar manufaktur yang dikeluarkan oleh EIA (Electronic Industries Association)" (Hariyanto, 2009)

"Resistor adalah komponen elektronika yang memiliki 2 kaki yang berfungsi untuk menghambar arus listrik dengan satuan nilai ohm"(Setiawan et al., 2014)

"Kapasitor adalah komponen elektronika yang dapat menyimpan muatan listrik dan umumnya memiliki beda fasa ( arus mendahului tegangan ) yang lebih mendekati dibandingkan dengan induktor. Oleh karenanya kapasitor menyerap daya lebih sedikit dari pada induktor ( dalam nilai yang sama ). Kapasitor terdiri dari beberapa 
tipe, tergantung dari bahan dielektriknya.Untuk lebih sederhanya dapat dibagi menjadi 3 bagian, yaitu kapasitor electrostatic, electrolytic dan electrochemical." (Noor \& Saputera, 2014)

"Salah satu komponen elektro yang berkembang adalah kapasitor atau kondensator, fungsi dari kapasitor adalah untuk menyimpan muatan listrik atau energi listrik. Kapasitor yang banyak digunakan sekarang merupakan perkembangan dari kapasitor primitif yang kemudian menjadi cikal bakal kapasitor yang ada sekarang." (Irawan \& Desmulyati, 2017)

"Model kapasitor pertama diciptakan di Belanda, tepatnya di kota Leyden pada abad ke-18 oleh para eksperimentalis fisika. Kapasitor adalah alat (komponen) yang mampu menyimpan muatan listrik yang besar untuk sementara waktu. Kapasitor terdiri atas keping-keping logam yang disekat satu sama lain dengan isolator. Isolator penyekat tersebut disebut dengan zat dielektrik." (Chanif et al., 2014)

"Kapasitor adalah komponen elektronika yang dapat menyimpan muatan listrik dengan nilai satuan farad" (Fauzi et al., 2018)

\section{METODE}

Pada penelitian ini sebelum penulis membuat program maka penulis melakukan tahapan dalam metode penilitian yaitu berupa analisa kebutuhan, melakukan desain aplikasi dan testing (uji coba) serta metode pengumpulan data yaitu dengan melakukan observasi dan studi kepustakaan.

\section{Analisa Penelitian}

Mengimplementasikan aplikasi yang akan dibuat penulis memerlukan analisa untuk kebutuhan dalam perancangannya diantaranya:
1. Analisa kebutuhan

Perancangan aplikasi ini membutuhkan suatu perangkat yang diantaranya adalah hardware berupa laptop dengan spesifikasi prosesor intel core i3 1,90 GHZ, RAM $10 \mathrm{~GB}$, video card $1 \mathrm{~GB}$, hardisk $500 \mathrm{~GB}$ dan software yaitu windows 1064 bit, android studio, Java JDK (Java Development kit) dan Android SDK (Standart Development Kit).

\section{Desain}

Dalam mendesain program penulis menggunakan android studio. Diantara fitur android studio disediakan konsep GUI (Graphical User Interface) sehingga memudahkan seorang program dalam mendesain. Adapun jika ingin mendesain secara manual pun bisa, sedangkan konsep OOP (Objeck Oriented Program) adalah konsep pemrograman java.

\section{Testing}

Untuk melakukan uji coba program yang sudah dibuat, penulis menggunakan Android Virtual Device (AVD) yang merupakan emulator untuk menjalankan program aplikasi android, $A V D$ ini nantinya yang kita jadikan sebagai tempat test dan menjalankan aplikasi android yang kita buat, $A V D$ berjalan di Virtual Machine. Jika pengujian di $A V D$ tidak ada kesalahan maka aplikasi android diinstall kedalam Mobile dengan operasi Sistem Android.

\section{Metode pengumpulan data}

1. Metode Observasi, yaitu perbandingan terhadap aplikasi elektronika yang sudah dibuat sebelumnya.

2. Metode Studi Kepustakaan, yaitu pengambilan data dengan cara mengambil materi-materi yang berhubungan dengan judul karya ilmiah melalui buku-buku dan jurnal. 


\section{HASIL DAN PEMBAHASAN \\ Hasil penilitian}

Hasil dari rancangan program yang dibuat dalam penelitian ini adalah.

1. Membangun sebuah aplikasi android kalkulator komponen elektronika dasar dimana aplikasi ini dapat membantu teknisi reparasi perangkat elektronika dalam mereparasi perangkat-perangkat elektronika yaitu ketika dalam pembacaan kode-kode komponen elektronika yang sangat unik dan memiliki arti tertentu dalam nilai komponennya.

2. Aplikasi ini juga berguna untuk mengedukasi para pelajar yang mempelajari ilmu elektronika

\section{Pembahasan}

Pada penelitian ini penulis membandingkan aplikasi yang telah dibuat pada penelitian sebelumnya yaitu dengan judul "Aplikasi Perhitungan Kapasitor Surface Mount Device" yang dimana penelitian tersebut dilakukan oleh Basorudin dan Agus Irawan yang menerangkan bahwa "Aplikasi ini di buat untuk memudahkan teknisi handphone untuk mengenali komponen kapasitor $S M D$, dikarenakan setiap perusahaan yang memproduksi kapasitor SMD mempunyai standar yang berbeda dalam setiap penilaian kodenya "(Basorudin \& Irawan, 2016)

Penulis mengamati bahwa pada aplikasi tersebut terdapat kekurangan dari segi fitur pembacaan komponenkomponen $S M D$, yang dimana hanya membaca komponen kapasitor SMD saja, sedangkan penelitian yang dibuat oleh penulis mencakup komponen-komponen lainnya, tidak hanya komponen kapasitor $S M D$, fitur lain tersedia dan lebih lengkap yaitu terdapat fitur pembacaan komponen resistor SMD dan terdapat pula komponen elektronika yang konvensional, Inilah salah satu keunggulan aplikasi yang dibuat oleh penulis, lebih lengkap untuk fitur-fitur pembacaan komponennya.

Berikut adalah hasil dari penelitian yang penulis lakukan yaitu desain aplikasi yang sudah running yaitu menu utama menampilkan icon komponen-komponen elektronika.

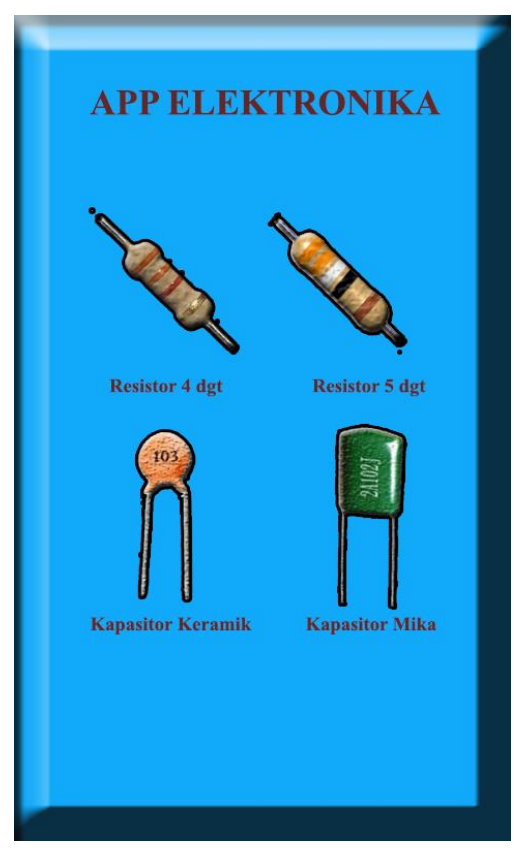

Gambar 1. Menu Aplikasi 


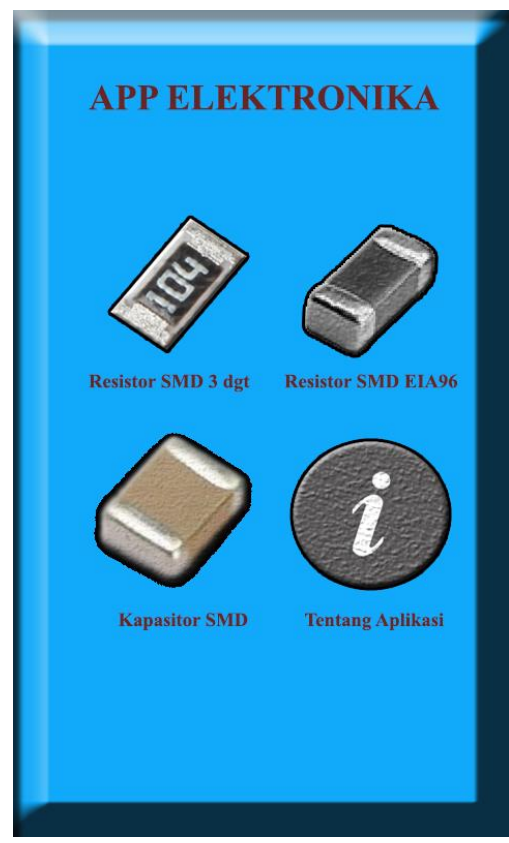

Gambar 2. Menu Aplikasi

Gambar 1 dan Gambar 2 memperlihatkan halaman awal yang akan muncul pada saat pertama kali aplikasi dijalankan. Halaman awal ini berisikan menu utama yang dapat diakses oleh user sesuai dengan kebutuhan. Total terdapat 8 menu yang dapat diakses oleh pengguna sesuai dengan fungsinya masing-masing.
Sesuai dengan fungsi utamanya Aplikasi ini membantu pengguna dalam menghitung nilai komponen elektronika atau sebagai kalkulator. Dalam aplikasi ini terdapat 4 buah menu yang untuk perhitungan nilai komponen resistor, 3 buah menu sebagai kalkulator kapasitor, dan 1 buah menu yang berisikan informasi mengenai aplikasi.

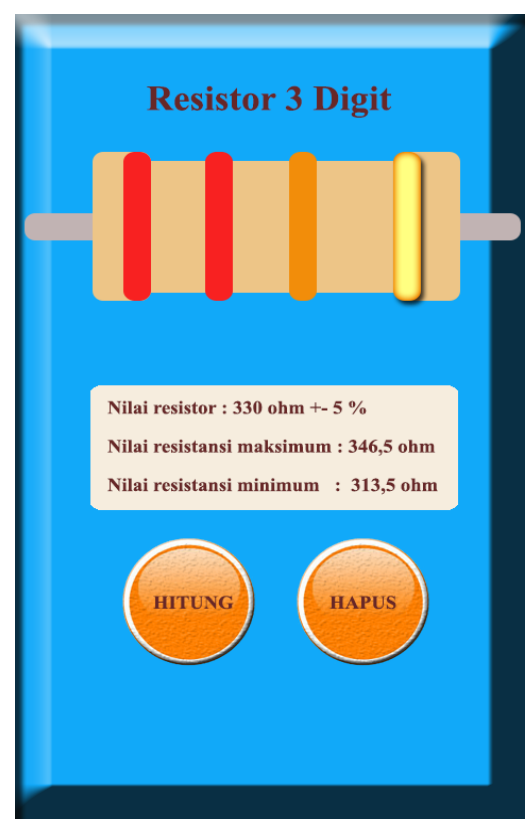

Gambar 3. Menu Kalkulator Resistor 3 Digit 
Gambar 3 memperlihatkan tampilan Aplikasi ketika menghitung nilai komponen dari salah satu Resistor 3 digit. Terlihat ketika aplikasi dijalankan sesuai dengan inputan warna yang dimasukkan maka aplikasi otomatis akan menmpilkan hasil berupa Nilai Resistor, Nilai Resistansi Minimum dan Maksismum. Begitu juga dengan Gambar
4 yang memperlihatkan tampilan perhitungan dari Resistor 5 digit. Gambar 5 memperlihatkan kalkulator perhitungan dari Resistor SMD EIS96, sesuai dengan jenisnya maka pada menu ini hanya ditampilkan nilai resistornya saja. Sementara pada Gambar 6 diperlihatkan tampilan perhitungan dari kapasitor keramik.

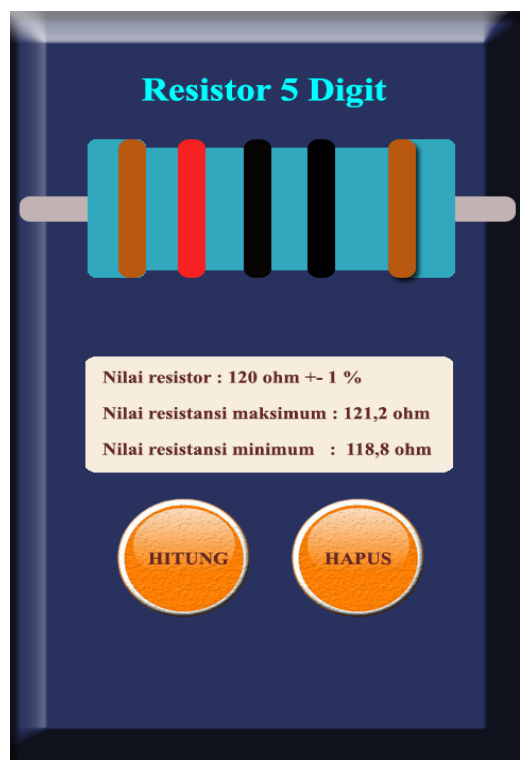

Gambar 5. Resistor 5 Digit

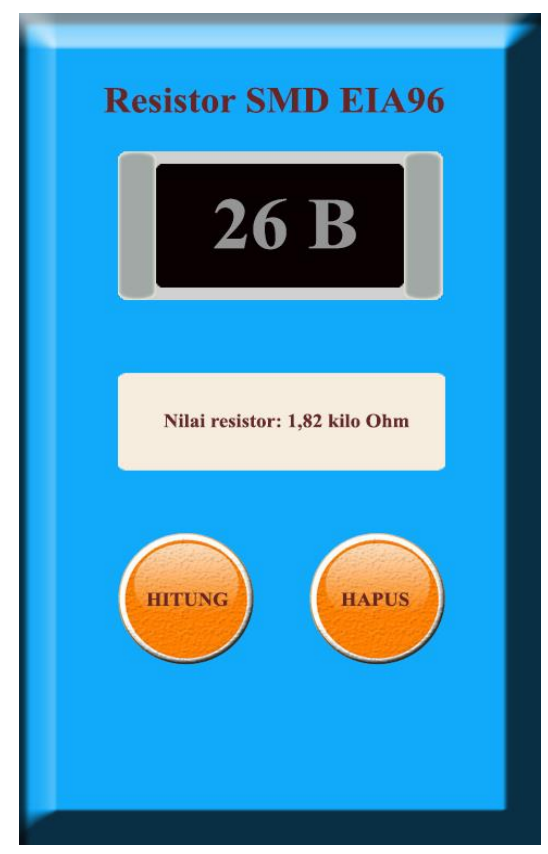

Gambar 6. Resistor EIA96 


\section{KESIMPULAN DAN SARAN Kesimpulan}

Setelah penulis membuat aplikasi android ini, disimpulkan bahwa aplikasi ini sangat berguna untuk membantu teknisi reparasi perangkat elektronika khususnya ketika para teknisi tersebut meraparasi perangkat-perangkat motherboard baik itu motherboard handphone maupun komputer. Hal ini dibuktikan melalui survey yang penulis lakukan dengan cara memberikan aplikasi yang penulis buat terhadap para teknisi tersebut dan tentunya selain itu aplikasi ini juga berguna untuk mengedukasi para pelajar yang mempelajari ilmu elektronika.

\section{Saran}

Karena masih banyak komponen yang belum dibuat kalkulatornya, kedepannya pada penelitian selanjutnya dapat dibuat kalkulator komponenkomponen elektronika lainnya. Lalu mungkin ditambahkan fitur-fitur lainnya seperti pengetahuan elektronika dan tampilan desainnya yang lebih interaktif.

\section{DAFTAR PUSTAKA}

Basorudin, \& Irawan, A. (2016). Aplikasi Perhitungan Kapasitor Surface Mount Device (SMD). Riau Journal Of Computer Science, 3(1), 49-62.

Chanif, M., Sarwito, S., \& K, E. S. (2014). Analisa Pengaruh Penambahan Kapasitor Terhadap Proses Pengisian Baterai Wahana Bawah Laut. Jurnal Teknik Pomits, $3(1), 1-6$.
Fauzi, A., Pernando, F., \& Raharjo, M. (2018). Penerapan Metode Haversine Formula Pada Aplikasi Pencarian Lokasi Tempat Tambal Ban Kendaraan Bermotor Berbasis Mobile Android. Jurnal Teknik Komputer, IV(2), 56-63.

Hariyanto, D. (2009). Studi Penentuan Nilai Resistor Menggunakan Seleksi Warna Model Hsi Pada Citra 2D. TELKOMNIKA (Telecommunication Computing Electronics and Control), 7(1), 13. Irawan, A., \& Desmulyati. (2017). Aplikasi Perhitungan Kapasitor Surface Mount Device. Jurnal Teknik Informatika Fakultas Ilmu Komputer Universitas Pasir Pengaraian, 3(1), 49-62.

Kamelia, L., Sukmawiguna, Y., \& Adiningsih, N. U. (2017). Rancang Bangun Sistem Exhaust Fan Otomatis Menggunakan Sensor Light Dependent Resistor. Teknik Elektro,Fakultas Sains Dan Teknologi, UIN SGD Bandung, $X(1), 154-169$.

Noor, S., \& Saputera, N. (2014). Efisiensi Pemakaian Daya Listrik Menggunakan Kapasitor Bank. Poros Teknik, 6(2), 1-6.

Setiawan, A., Maulana, A., Faisal, M., \& Pernando, F. (2019). Aplikasi Perhitungan Resistor SMD Berbasis Android. Jurnal Akrab Juara, 4, 1 13.

Setiawan, A., Mulyani, A., \& Budihartanti, C. (2014). Perhitungan Komponen Elektronika Berbasis Android. XI(2), 149-157. 
